\title{
Synthesis, physical and chemical research of alkyl-, heterylderivatives of 7'-((4-ethyl-5-thio-4H-1,2,4-triazoles-3-yl)methyl)theophylline
}

\author{
Zaporizhzhia State Medical University
}

Key words: 1,2,4-triazoles, Theophylline, Synthesis,

IR-spectrometry, ${ }^{1} \mathrm{H}$ NMR spectrometry.
Aim. To analyze the alkyl-, heterylderivatives of 7'-((4-ethyl-5-thio-4H-1,2,4-triazoles3-yl)methyl)theophylline their mother substance has been synthesized and its interaction with halogenalkane and halogenheteryle has been carried out.

Methods and results. The physical and chemical properties of the obtained compounds have been studied and their structures have been confirmed by elemental analysis, infrared spectrometry, ${ }^{1} \mathrm{H}$ NMR spectrometry, UV spectrophotometry and gas chromatography mass spectrometry. Preliminary computer study of acute toxicity and biological activity has been also carried out.

Results and their discussion. Theophylline was used as starting substance from which through series successive stages of transformation (electrophilic substitution reaction, hydrazinolysis, etherification and intramolecular alkaline heterocyclisation) starting thiol and alkyl derivatives were obtained. Alkyl derivatives were obtained in propanol-1 with heating. Synthesized substances were crystallized from methanol.

Signals of methyl groups of theophylline, $\mathrm{N}^{7}-\mathrm{CH}_{2}$-groups, thioalkyl fragments are fixed in ${ }^{1} \mathrm{H}$ NMR spectrum of obtained compound. Protons of the S-alkyl fragments resonate in a strong field as a multiplet in area $1.53-1.01 \mathrm{ppm}$. Protons of $\mathrm{N}_{-} \mathrm{C}_{2} \mathrm{H}_{5}$ fragment are fixed also as a multiplet at $1.74-1.62 \mathrm{ppm}$. $\mathrm{CH}_{2}$-group is presented by protons signals as a singlet at $5.71 \mathrm{ppm}$. Protons of $\mathrm{CH}_{3}$-group of the xanthine sinton resonate at 2.95 and at $3.25 \mathrm{ppm}$.

Personality of the compounds has been established using chromato-mass spectrometry.

Conclusion. 13 New compounds have been obtained and their structure has been confirmed.

Indicators of computer evaluation of synthesized compounds using the PASS program have been researched. By means of prediction, results identified the most perspective compounds for testing the biological activity in vitro. During the analysis of obtained results, it was able to establish that obtained compounds possess different types of biological activity. Diuretic and analeptic activities dominate among the most likely types of that predicted activities for all 13 compounds.

Синтез і фізико-хімічні дослідження алкіл- та гетерилпохідних 7'-((4-етил-5-тіо-4H-1,2,4-тріазол-3-іл)метил)теофіліну А. С. Гоиуля

Мета роботи - для дослідження алкіл- та гетерилпохідних 7'-((4-етил-5-тіо-4H-1,2,4-тріазол-3-іл)метил)теофіліну здійснити синтез вихідної речовини й дослідити іï взаємодію з галогеналканами та галогенгетерилами.

Матеріали та методи. Як вихідну сполуку використали теофілін, з якого через ряд послідовних стадій (реакції електрофільного заміщення, гідразинолізу, етерифікації та внутрішньомолекулярної лужної гетероциклізації) отримали вихідний тіол та його алкілпохідні. Алкілпохідні були синтезовані в середовищі пропанолу-1 при нагріванні. Синтезовані сполуки кристалізовано в середовищі метанолу.

Результати. Досліджено фізико-хімічні властивості сполук, що отримали, їхня будова доведена за допомогою елементного аналізу, ІЧ-спектрометрії, ${ }^{1} \mathrm{H}$ ЯМР-спектрометрії, УФ-спектрофотометрії та хромато-мас-спектрометрії. Сигнали протонів метильної групи теофіліну, метиленової групи, тіоалкільних фрагментів були зафіксовані при здійсненні ${ }^{1} \mathrm{H}$ ЯМР-спектрометрії. Сигнали протонів S-алкільних фрагментів реєструються у сильному полі у вигляді мультиплета при 1,53-1,01 м. ч. Сигнали протонів $\mathrm{N}-\mathrm{C}_{2} \mathrm{H}_{5}$ фрагмента також фіксуються у вигляді мультиплета при 1,74-1,62 м. ч. Метиленова група представлена сигналами протонів при 5,71 м. ч. у вигляді синглету. Протони метильної групи резонують у вигляді синтону при 2,95 і при 3,25 м. ч. Індивідуальність сполук, що отримали, встановлена за допомогою хромато-мас-спектрометрії. Здійснили попереднє комп'ютерне дослідження параметрів гострої токсичності та біологічної активності.

Висновки. Отримано 13 сполук і доведена їхня структура. Досліджені показники комп’ютерного оцінювання сполук, котрі синтезували, за допомогою онлайн-сервісу PASS. Визначені найбільш перспективні сполуки для тестування in vitro. Під час аналізу результатів вдалося встановити: сполуки, що отримали, можуть володіти різними видами біологічної активності. Серед найбільш імовірних видів активності, котрі передбачені для всіх 13 сполук, домінують сечогінний та аналептичний ефекти.

Ключові слова: 1,2,4-триазол, теофілін, синтез, ІЧ-спектрометрія, ${ }^{1}$ Н ЯМР спектрометрія.

Актуальні питання фармацевтичної і медичної науки та практики. - 2016. - № 2 (21). - С. 10 -14 


\section{Синтез и физико-химические исследования алкил- и гетерилпроизводных 7'-((4-этил-5-тио-4Н-1,2,4-триазол-3-ил) метил)теофиллина}

А. С. Гоиуля

Цель работы - для исследования алкил- и гетерилпроизводных 7'-((4-этил-5-тио-4H-1,2,4-триазол-3-ил)метил)теофиллина провести синтез исходного вещества и изучить его взаимодействие с галогеналканами и галогенгетерилами.

Материалы и методы. В качестве исходного соединения был использован теофиллин, из которого через ряд последовательных стадий (реакции электрофильного замещения, гидразинолиза, этерификации и внутримолекулярной щелочной гетероциклизации) был получен тиол и его алкилпроизводные.

Алкилпроизводные были синтезированы в среде пропанола-1 при нагревании. Полученные соединения перекристаллизованы в среде метанола.

Результаты. Установлены физико-химические свойства полученных веществ, их строение доказано с помощью элементного анализа, ИК-спектрометрии, 'Н ЯМР-спектрометрии, УФ-спектрофотометрии и хромато-масс-спектрометрии. Сигналы протонов метильной группы теофиллина, метиленовой группы, тиоалкильных фрагментов были зафиксированы при проведении ${ }^{1} \mathrm{H}$ ЯМР-спектрометрии. Сигналы протонов S-алкильных фрагментов регистрируются в сильном поле в виде мультиплета при 1,53-1,01 м. д. Сигналы протонов $\mathrm{N}_{2} \mathrm{C}_{2} \mathrm{H}_{5}$ фрагмента также фиксируются в виде мультиплета при 1,74-1,62 м. Д. Метиленовая группа представлена сигналами протонов при 5,71 м. д. в виде синглета. Протоны метильной группы резонируют в виде синтона при 2,95 и при 3,25 м. д. Индивидуальность полученных соединений установлена с помощью хромато-масс-спектрометрии. Осуществлено предварительное компьютерное исследование параметров острой токсичности и биологической активности.

Выводы. Получено 13 соединений и доказана их структура. Исследованы показатели компьютерной оценки синтезированных соединений с помощью онлайн-сервиса PASS. Определены наиболее перспективные соединения для тестирования in vitro. B ходе анализа результатов удалось установить, что полученные соединения могут обладать различными видами биологической активности. Среди наиболее вероятных видов активности, которые могут проявиться у всех 13 соединений, доминируют мочегонный и аналептический эффекты.

Ключевые слова: 1,2,4-триазол, теофиллин, синтез, ИК-спектрометрия, ${ }^{1}$ Н ЯМР-спектрометрия.

Актуальные вопросы фармацевтической и медицинской науки и практики. - 2016. - № 2 (21). - С. 10-14

$\mathrm{H}$ uman life level improvement is an actual problem nowadays [4-8]. Especially it is connected with such areas as medicine and pharmacy. One of the ways in order to solve this question is search and study of new biologically active compounds [1,2]. Particular interest in this direction is caused by azocompounds.

1,2,4-Triazole fragment is a successful synton, used at medicines creation [10]. Therefore, combining it with different nature radicals may be interesting for further research $[3,9]$. Thus, increasing the probability of new pharmacological effects appearance and strengthening of existing is possible. The fact that of 1,2,4-triazole derivatives are often marked by low toxicity parameters simultaneously with high efficiency is also important. Based on this fact, absolute value is studying the effect of different syntons in 1,2,4-triazole structure on different types of biological activity. Thus, research of derivatives of such heterocyclic system is actual and practically significant.

The purpose of work was synthesis and research of properties of alkyl-, heterylderivatives of 7' -((4-ethyl-5-thio$4 H$-1,2,4-triazoles-3-yl)methyl)theophylline.

\section{Materials and methods}

During the research process as initial material for synthesis of new series of compounds the theophylline has been chosen. It is important to note that considering the variety and strength of pharmacological effects, that occur, this structure takes its rightful place among the heterocyclic compounds [4-7]. 7'-((4-Ethyl-5-thio-4H-1,2,4-triazoles-3-yl)methyl) theophyllin has been received from theophylline through series of successive stages.

Propyl 2-(theophylline-7'-yl)acetate, 2-(theophylline-7'-yl)acetohydrazide, 2-(2-(theophylline-7'-yl)
acetyl)-N-ethylhydrazynecarbothioamide, 7'-((3-thio-4ethyl-4H-1,2,4-triazoles-5-yl)methyl)theophylline have been obtained in accordance with methods, described in the literature [1,9].

Alkylderivatives of 7'-((4-ethyl-5-thio-4H-1,2,4-triazole-3$y$ l)methyl) theophylline (Fig. 1). The mixture of $0.005 \mathrm{~mol}$ of 7'-((4-ethyl-5-thio-4H-1,2,4-triazole-3-yl)methyl)-theophylline and an equivalent amount of sodium hydroxide was dissolved in $30 \mathrm{ml}$ of propanol-1 also an equivalent amount of halogenalkane (1-bromopropane, 1-bromobutane, 1-bromopentane, 1-bromohexane, 1-bromoheptane, 1-bromooctane, 1-bromononane, 1-bromodecane, chlorocyclohexane) was added. Heated for 2 hours, cooled, the precipitate was filtered, washed with water and crystallized from methanol (Table 1).

Heterylderivatives of 7'-((4-ethyl-5-thio-4H-1,2,4-triazoles3-yl)methyl)-theophylline (Fig. 1). The mixture of $0.1 \mathrm{~mol}$ of 7'-((4-ethyl-5-thio-4H-1,2,4-triazoles-3-yl)methyl)theophylline and an equivalent amount of sodium hydroxide was dissolved in $30 \mathrm{ml}$ of propanol-1 also an equivalent number of halogenheteryle (benzylchloride, 2-chloropyrimidine, 2-bromothiophene) was added. Heated for 2 hours, cooled, the precipitate was filtered, washed with water, dried and crystallized from methanol (Table 1).

\section{Results and their discussion}

In the ${ }^{1} \mathrm{H}$ NMR spectra of obtained compounds a number of signals is observed. Protons of the S-alkyl fragments resonate in a strong field as a multiplet in area 1.53-1.01 ppm. Protons of $\mathrm{N}-\mathrm{C}_{2} \mathrm{H}_{5}$ fragment are fixed also as a multiplet at 1.74-1.62 ppm. $\mathrm{CH}_{2}$-group is presented by protons signals as a singlet at $5.71 \mathrm{ppm}$. Protons of $\mathrm{CH}_{3}$-group of the xanthine sinton resonate at 2.95 and at $3.25 \mathrm{ppm}$. Methyne group is described with signals at $5.71 \mathrm{ppm}$. 


\section{Physical-chemical properties of the synthesized compounds}<smiles>[R]Sc1nnc(Cn2cnc3c2c(=O)n(C)c(=O)n3C)n1CC</smiles>

\begin{tabular}{|c|c|c|c|c|}
\hline № & $R$ & $\mathrm{~T}_{\mathrm{m} .,}{ }^{\circ} \mathrm{C}$ & Yield, \% & Empirical formula \\
\hline 1 & $\mathrm{H}$ & $>250$ & 79 & $\mathrm{C}_{12} \mathrm{H}_{15} \mathrm{~N}_{7} \mathrm{O}_{2} \mathrm{~S}$ \\
\hline 2 & $\mathrm{C}_{3} \mathrm{H}_{7}$ & $125-128$ & 81 & $\mathrm{C}_{15} \mathrm{H}_{21} \mathrm{~N}_{7} \mathrm{O}_{2} \mathrm{~S}$ \\
\hline 3 & $\mathrm{C}_{4} \mathrm{H}_{9}$ & $140-143$ & 73 & $\mathrm{C}_{16} \mathrm{H}_{23} \mathrm{~N}_{7} \mathrm{O}_{2} \mathrm{~S}$ \\
\hline 4 & $\mathrm{C}_{5} \mathrm{H}_{11}$ & $135-137$ & 69 & $\mathrm{C}_{17} \mathrm{H}_{25} \mathrm{~N}_{7} \mathrm{O}_{2} \mathrm{~S}$ \\
\hline 5 & $\mathrm{C}_{6} \mathrm{H}_{13}$ & $100-103$ & 76 & $\mathrm{C}_{18} \mathrm{H}_{27} \mathrm{~N}_{7} \mathrm{O}_{2} \mathrm{~S}$ \\
\hline 6 & $\mathrm{C}_{7} \mathrm{H}_{15}$ & 104-106 & 86 & $\mathrm{C}_{19} \mathrm{H}_{29} \mathrm{~N}_{7} \mathrm{O}_{2} \mathrm{~S}$ \\
\hline 7 & $\mathrm{C}_{8} \mathrm{H}_{17}$ & 96-99 & 73 & $\mathrm{C}_{20} \mathrm{H}_{31} \mathrm{~N}_{7} \mathrm{O}_{2} \mathrm{~S}$ \\
\hline 8 & $\mathrm{C}_{9} \mathrm{H}_{19}$ & $105-107$ & 69 & $\mathrm{C}_{21} \mathrm{H}_{33} \mathrm{~N}_{7} \mathrm{O}_{2} \mathrm{~S}$ \\
\hline 9 & $\mathrm{C}_{10} \mathrm{H}_{21}$ & $108-110$ & 94 & $\mathrm{C}_{22} \mathrm{H}_{35} \mathrm{~N}_{7} \mathrm{O}_{2} \mathrm{~S}$ \\
\hline 10 & & $>245$ & 67 & $\mathrm{C}_{18} \mathrm{H}_{25} \mathrm{~N}_{7} \mathrm{O}_{2} \mathrm{~S}$ \\
\hline 11 & & $184-186$ & 90 & $\mathrm{C}_{19} \mathrm{H}_{21} \mathrm{~N}_{7} \mathrm{O}_{2} \mathrm{~S}$ \\
\hline 12 & & $186-188$ & 52 & $\mathrm{C}_{16} \mathrm{H}_{17} \mathrm{~N}_{9} \mathrm{O}_{2} \mathrm{~S}$ \\
\hline 13 & & $234-235$ & 53 & $\mathrm{C}_{16} \mathrm{H}_{17} \mathrm{~N}_{7} \mathrm{O}_{2} \mathrm{~S}_{2}$ \\
\hline
\end{tabular}

Cont. table 1

\begin{tabular}{|c|c|c|c|c|c|c|c|c|}
\hline \multirow{2}{*}{ № } & \multicolumn{4}{|c|}{ Found, \% } & \multicolumn{4}{c|}{ Calculated, \% } \\
\cline { 2 - 9 } & $\mathrm{C}$ & $\mathrm{H}$ & $\mathrm{N}$ & $\mathrm{S}$ & $\mathrm{C}$ & $\mathrm{H}$ & $\mathrm{N}$ & $\mathrm{S}$ \\
\hline 1 & 44,28 & 4,54 & 25,76 & 8,42 & 44,32 & 4,52 & 25,84 & 8,45 \\
\hline 2 & 49,45 & 5,83 & 26,94 & 8,84 & 49,57 & 5,82 & 26,98 & 8,82 \\
\hline 3 & 50,79 & 6,15 & 25,94 & 8,51 & 50,91 & 6,14 & 25,98 & 8,49 \\
\hline 4 & 52,02 & 6,45 & 25,01 & 8,21 & 52,15 & 6,44 & 25,04 & 8,19 \\
\hline 5 & 53,18 & 6,72 & 24,14 & 7,93 & 53,31 & 6,71 & 24,18 & 7,91 \\
\hline 6 & 54,26 & 6,98 & 23,34 & 7,66 & 54,39 & 6,97 & 23,37 & 7,64 \\
\hline 7 & 55,27 & 7,22 & 22,58 & 7,42 & 55,40 & 7,21 & 22,61 & 7,40 \\
\hline 8 & 56,18 & 7,44 & 21,88 & 7,18 & 56,32 & 7,43 & 21,91 & 7,16 \\
\hline 9 & 57,10 & 7,65 & 21,21 & 6,97 & 57,24 & 7,64 & 21,24 & 6,95 \\
\hline 10 & 53,45 & 6,25 & 24,26 & 7,97 & 53,58 & 6,24 & 24,30 & 7,95 \\
\hline 11 & 55,32 & 5,15 & 23,79 & 7,81 & 55,46 & 5,14 & 23,83 & 7,79 \\
\hline 12 & 47,99 & 4,30 & 31,51 & 8,04 & 48,11 & 4,29 & 31,56 & 8,03 \\
\hline 13 & 47,51 & 4,26 & 24,26 & 15,92 & 47,63 & 4,25 & 24,30 & 15,89 \\
\hline
\end{tabular}

In the IR-spectrum of synthesized alkyl derivatives we observe deformation vibrations of C-S-H fragment of alkyl groups in ranges from 630 to $1400 \mathrm{~cm}^{-1}$ and $\mathrm{H}-\mathrm{C}-\mathrm{H}$ fragment in a narrow area of frequency $1370-1500 \mathrm{~cm}^{-1}$. For example, for $\mathrm{CH}_{3}$-group $\delta$-vibrations occupied area at $1378-1380 \mathrm{~cm}^{-1}$, and for $\mathrm{C}_{4} \mathrm{H}_{9}$ - at $1390-1410 \mathrm{~cm}^{-1}$. Valence vibrations of bonds of $\mathrm{C}-\mathrm{H}$ alkyl groups form bands in area $2850-3100 \mathrm{~cm}^{-1} .780-840 \mathrm{~cm}^{-1}$ occupies a band of average intensity with a complex circuit that has several peaks (skeletal vibrations of C-C bonds).

By means of program PASS and GUSSAR products, prediction of the acute toxicity of synthesized compounds has been performed. It has been established that these compounds belong to low-toxic, which correlates with the known literature facts, and also help to open medical and biological potential of these compounds. 


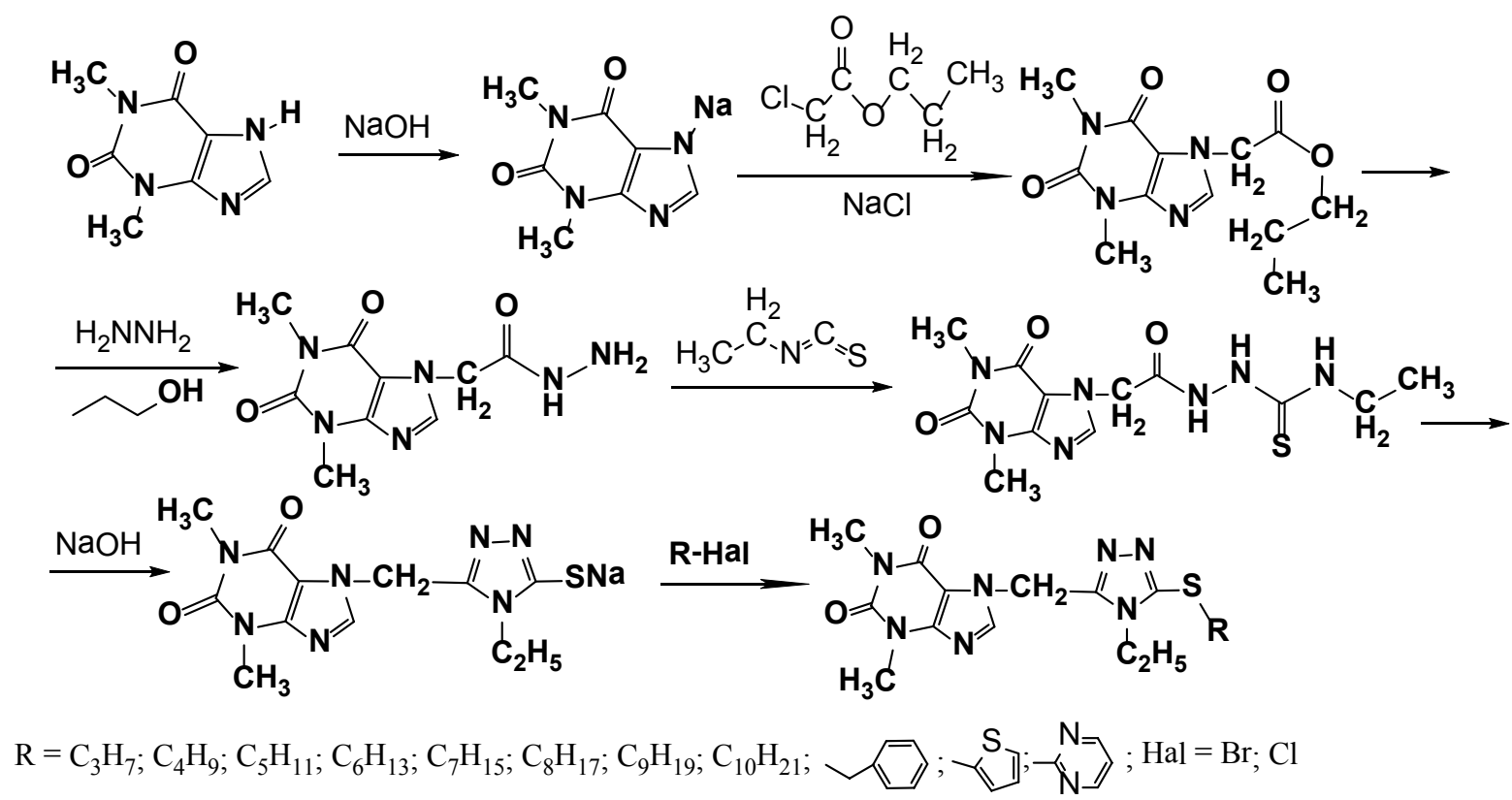

Fig. 1. Scheme of the synthesis of S-derivatives 7'-((3-thio-4-ethyl-4H-1,2,4-triazole-5-yl)methyl)theophylline.

\section{Conclusions}

The optimal conditions for obtaining various derivatives of 7'-((4-ethyl-5-thio-4H-1,2,4-triazole-3-yl)methyl)-theophylline with halogenalkanes and halogen containing heteryle compounds have been established. Computer estimation indexes of synthesized compounds have been investigated using PASS program. The most promising compounds for in vitro testing have been determined. Diuretic and analeptic activities dominate in all 13 compounds.

Conflicts of Interest: author have no conflict of interest to declare.

\section{References}

1. Hotsulya, A. S., Mikolasiuk, O. O., Panasenko, O. I., et al. (2014). Syntez i doslidzhennia fizyko-khimichnykh vlastyvostei solei 2-(5-((teofilin-7-il)metyl)-4-fenil-4H-1,2,4-triazlol-3-ilitio)atsetatnoi kysloty [Synthesis and investigation of the physico-chemical properties of 2-(5-((theophylline-7'-yl) methyl)-4-phenyl-4H-1,2,4-triazole-3-ylthio)acetic acid salts]. Zaporozhskij medicinskij zhurnal, 1(82), 91. [in Ukrainian].

2. Hotsulia, A. S., Panasenko, O. I., \& Knysh, Ye. H. (2015). UF-spektrofotometrychne doslidzhennya 7-((3-tio-4-R-1,2,4triazol-3-il)metyl)-teofiliniv [UV-spectrophotometric study of the 7-((3-thio-4-R-1,2,4-triazole-3-yl)methyl)-theophyllines]. Farmatsevtychnyj zhurnal, 4, 65-70. [in Ukrainian].

3. Hotsulia, A. S., Panasenko, O. I., Knysh, Ye. H., \& Varynskyi, B. O. (2014). Syntez ta fizyko-khimichni vlastyvosti deiakykh pokhidnykh 7-((3-tio-4-R-4H-1,2,4-triazol-5-il)metyl)teofilinu [Synthesis and physico-chemical properties of some derivatives of 7-((3-thio-4R-4H-1,2,4-triazole-5-yl)methyl)-theophylline]. Farmatsevtychnyi zhurnal, 6, 43-53. [in Ukrainian].

4. Levich, S. V., Shkoda, O. S., \& Aleksandrova, K. V. (2013). Syntez ta fizyko-khimichni vlastyvosti S-zamishchenykh pokhidnykh 3-benzyl-8-metyl-7-[(4-fenil-5-tio-4N-1,2,4triazol-3-il)metyl]-ksantynu [Synthesis and physic-chemical properties derivatives of 8-sustituted 3-benzylxanthines as perspective compounds for search of biologically active substances]. Aktualni pytannia farmatsevtychnoi i medychnoi nauky ta praktyky, 1(11), 54-58. [in Ukrainian].

5. Yurchenko, D. M., Aleksandrova, K. V., Romanenko, M. I., Samura, B. A., \& Taran, A. V. (patentee) (2011). Patent Ukrainy 61715, MPK (2011.01), S07D 473/00. Amid 4-fenil5-(3'-metylksantynil-7')metyl-1,2,4-triazolil-3-tioacetatnoyi kysloty, yakyy vyiavliaye diuretychnuy, protyzapalnu ta analhetychnu diyi. [Ukraine Patent 61715, IPC (2011.01) S07D 473/00. Amide of 4-phenyl-5-(3'-methylxanthinyl-7') methyl-1,2,4-triazolyl-3-thioacetic acid which exhibits a diuretic, anti-inflammatory and analgesic effect]. [in Ukrainian].

6. Yurchenko, D. M., Aleksandrova, K. V., Romanenko, M. I., \& Makoid O. B. (2011). Syntez, reaktsii ta fizyko-khimichni vlastyvosti pokhidnykh 8-tioksantynil-7-atsetatnykh kyslot [Synthesis, reaction and physic-chemical properties derivatives of 8-thioxanthinyl-7-acetic acid]. Aktualni pytannia farmatsevtychnoi i medychnoi nauky ta praktyky, XXIV (3), 104-108. [in Ukrainian].

7. Aleksandrova, K. V., Yurchenko, D. M., Romanenko, M. I., \& Martyniuk, O. O. (2010). Syntez ta fizyko-khimichni vlastyvosti esteriv ksantynil-7-otstovoi kysloty [Synthesis and physic-chemical properties ester of xanthinyl-7-acetic acid]. Aktualni pytannia farmatsevtychnoi i medychnoi nauky ta praktyky, XXIII, (1), 7-10. [in Ukrainian].

8. Kazunin, M. S., Prijmenko, A. O., Vasil'ev, D. A., \& Prijmenko, B. A. (2010). Sintez, fiziko-khimycheskie svojstva 3-(3-metilksantinil-8)-propanovoj kisloty i nekotorykh eyo proizvodnykh [Synthesis, physic-chemical properties 3-(3-methylxanthinyl-8)-propanoic acid and some of its derivatives]. Zaporozhskij medicinskij zhurnal, 3(12), 103. [in Ukrainian].

9. Gotsulya, A. S., Panasenko, O. I., Knysh, Ye. G., \& Knyazevich, P. S. (2015). Synthesis and physical-chemical research of 7-((3-thio-4-R-4H-1,2,4-triazole-5-yl)methyl)theophylline carbonyl derivatives. Zaporozhskij medicinskij zhurnal, 90, 103.

10. Lupascu, F. G., Dragostin, O. M., Foia, L., Lupascu, D., \& Profire, L. (2013). The synthesis and the biological evaluation of new thiazolidine-4-one derivatives containing a xanthine moiety. Molecules, 18, 9684-9703. doi:10.3390/ molecules 18089684 . 


\section{Information about author:}

Gotsulya A. S., MD, PhD, Assistant Professor of the Department of Toxicology and Inorganic Chemistry Zaporizhzhia State Medical University, E-mail: andrey_goculya@mail.ru.

\section{Відомості про автора:}

Гоцуля А. С., канд. фарм. наук, старший викладач каф. токсикологічної та неорганічної хімії, Запорізький державний медичний університет, E-mail: andrey_goculya@mail.ru.

Сведения об авторе:

Гоцуля А. С., канд. фарм. наук, старший преподаватель каф. токсикологической и неорганической химии, Запорожский государственный медицинский университет, E-mail: andrey_goculya@mail.ru. 